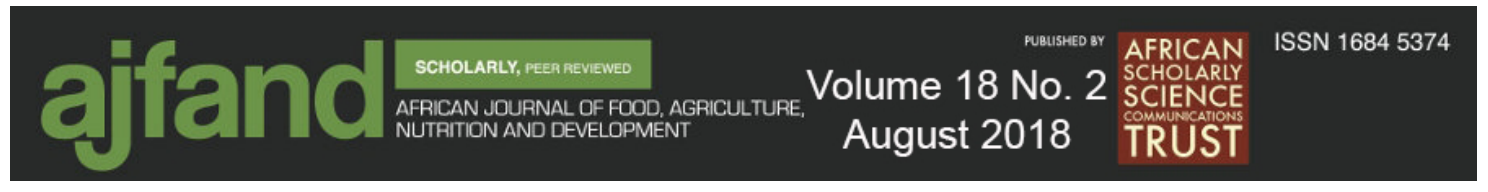

Afr. J. Food Agric. Nutr. Dev. 2018; 18(2): 13272-13286

DOI: 10.18697/ajfand.82.16630

EVALUATION OF NUTRIENTS AND ANTI- NUTRIENT PROPERTIES OF TRADITIONALLY PREPARED TRECULIA AFRICANA DECNE (BREAD FRUIT DIET AND TOASTED SEEDS)

\title{
Runsewe-Abiodun $\mathrm{TI}^{1^{*}}$, Aliyu $\mathrm{AO}^{2}$ and KS Oritogun ${ }^{3}$
}

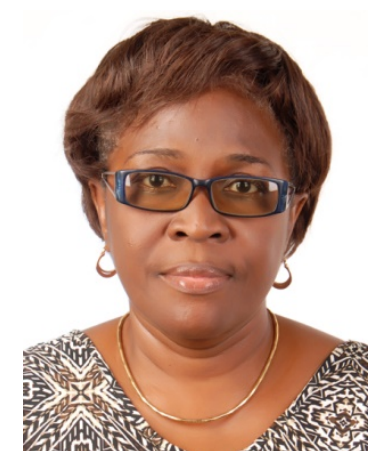

Runsewe-Abiodun Tamramat

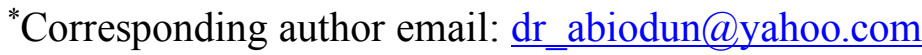

${ }^{1}$ Department of Paediatrics, Obafemi Awolowo College of Health Sciences, Olabisi

Onabanjo University, Ago-Iwoye, Ogun State, Nigeria

${ }^{2}$ Department of Chemistry, School of Sciences, Tai Solarin College of Education, Omu-Ijebu, Ogun State, Nigeria

${ }^{3}$ Department of Community Medicine and Primary Care, Obafemi Awolowo College of Health Sciences, Olabisi Onabanjo University, Ago-Iwoye, Ogun State, Nigeria 


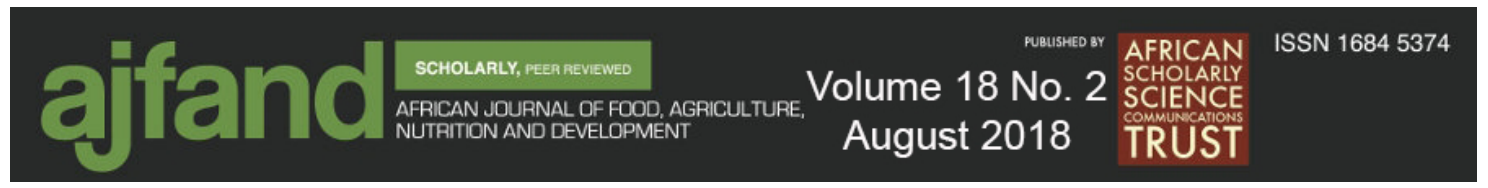

\begin{abstract}
Protein deficiency affects more than 170 million pre-school children and nursing mothers in developing countries creating a need for a strategy to improve the nutritional status of their diet through supplementation with plant proteins. The nutritional value of Treculia africana (African Breadfruit) has been extensively studied under laboratory conditions. Although the Breadfruit tree grows wildly in some West and Central African countries, and its seeds eaten in various forms by the populace, there has not been an attempt to evaluate its nutritive value as prepared at the home level. The goal of this study was, therefore, to evaluate the nutritive value of the seeds as indigenously prepared by the general populace in order to determine the suitability of its use as a good complementary diet. The raw seeds purchased in the Ikenne local government area (LGA) of Ogun State, Nigeria were subjected to cooking and toasting methods (using firewood) as practiced in the area. A proximate analysis was performed on the three samples (Raw, Cooked and Toasted) in order to evaluate the composition and some anti-nutritional factors of the Breadfruit seeds. Results showed that the cooked and toasted samples had better nutritive values as compared with the raw seeds; the mean \% protein content of the raw, cooked and toasted samples were $16.32 \pm 0.09,18.25 \pm 0.00$ and $17.22 \pm 0.04$, respectively. Ash content was $1.36 \pm 0.057,1.86 \pm 0.042$ and $1.83 \pm 0.007$, respectively, fat was $10.98 \pm 0.071$, $11.50 \pm 0.134$ and $13.74 \pm 0.233$, respectively and crude fiber was $1.25 \pm 0.007,2.13 \pm 0.014$ and $2.39 \pm 0.064$, respectively. The tannin level was higher in cooked and toasted seeds than in the raw seeds but was not in toxic amounts $(1.19 \mathrm{gm}, 3.50$ and 2.32 in the raw, cooked and toasted seeds, respectively). Phytate levels were generally lower in the cooked and toasted seeds; at 2.85\%, 1.99\%, and 2.24\% for raw, cooked and toasted seeds, respectively. This study showed that the two major modes of preparation of the African Breadfruit seeds retained high levels of nutrients with lower levels of anti-nutrients. The resulting meal/snack will be useful as a good complementary diet for the African child, especially in areas where it grows wildly as it will provide a more viable alternative to the currently known and consumed weaning diets among the rural population. Toasting the African Breadfruit seed will be particularly helpful for working mothers who require ready to eat food as the moisture content was lowered (and by extension the shelf life increased) by this method of processing.
\end{abstract}

Key words: Toasting, Proximate composition, Anti-nutritional factors, African Breadfruit, Complementary diet 


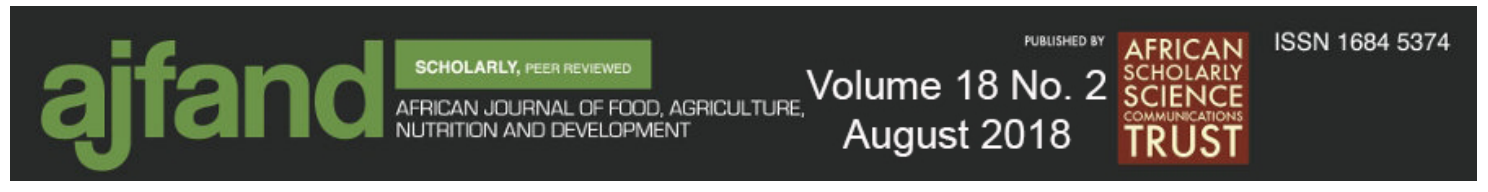

\section{INTRODUCTION}

Protein deficiency affects more than 170 million preschoolers and nursing mothers in developing countries [1]. The existing population growth reveals that the protein gap may gradually increase in the future unless well planned measures are taken to curb the situation [2]. However, provision of adequate animal protein is difficult and expensive. An alternative strategy for improving the nutritional status of the populace is to supplement the diet with plant proteins such as those found in vegetables, cereals and legumes.

Exclusive breastfeeding for the first six months provides enough energy and nutrients to meet bodily requirements of infants. The energy gap for the breastfed infant widens up to $548 \mathrm{kcal}$ by the $23^{\text {rd }}$ month and should be met through complementary foods [3]. Complementary feeding helps to transit the infant from breast milk to adult diet by expanding the food scope and including semi-solid and solid foods other than breast milk. In particular, the amount of protein needed from the complementary foods increases by about three folds with the progression of age from six months to two years [4].

Inadequate complementary foods and improper feeding practices are among the major reasons for nutrient deficiency in infants in the developing nations. The traditional weaning foods often used are bulky, lower in energy density, protein, micronutrient concentration and quality [5]. This has led researchers to look internally for locally available food sources of high nutritive value for example the African Breadfruit $[6,7$, $8,9]$.

The African Breadfruit seeds grow wildly in some of the districts in the southern part of Nigeria, Ghana and other countries in West Africa, and are readily available to the population. Although the seeds are well known by the populace [10], they are consumed in various forms either as a delicacy or snack $[8,11]$. Various authors have described the nutritive value of the seeds under laboratory conditions $[6,7]$. However, low utilization of these highly nutritive seeds has been attributed to the laborious processing method [8]. In addition, anti-nutritive factors such as hydrocyanic acid, oxalates, phytates and tannins have been found in the African Breadfruit seeds [9].

Consumption of these anti-nutritive factors at high levels often results in toxicity and eventual death [12]. Studies have shown that the activity of these compounds may be reduced/removed by de-hulling, soaking, cooking, toasting and fermenting [13,14].

The African Breadfruit porridge (as prepared and eaten by the local populace in the South Western part of Nigeria) has been used to rehabilitate children with mild to moderate malnutrition in Ikenne Local Government Area of Ogun State, South Western Nigeria [10]. However, no effort has been made to determine the suitability and safety of this very well-known local delicacy.

The objective of the current study was to evaluate the proximate composition, nutritive value and anti-nutritional content of the seeds as consumed in the community (porridge 


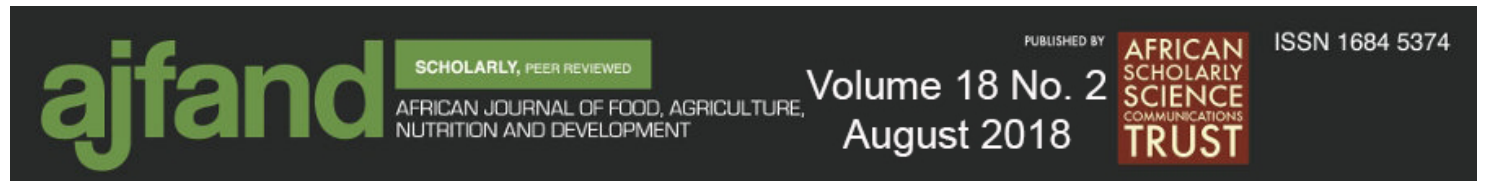

meal and snacks). The outcome of this study would help in determining the suitability of these traditionally processed foods as good complementary diets.

\section{MATERIAL AND METHODS}

Treculia africana Decne (African Breadfruit) seeds used for this study were purchased from a local market in Ogere town, Ikenne Local Government, Ogun State, Nigeria.

\section{Preparation of the seeds}

The partially de-hulled seeds and chaff from the processed African Breadfruit seeds purchased from the local markets were sorted out. Three portions of $300 \mathrm{~g}$ each of the seeds were weighed and labeled as A, B, C.

The A portion was left as the raw seed, packed in a polythene bag and labeled as sample A.

The second portion (B) was thoroughly washed in running tap water. The seeds were adjudged to be clean when the washing water was clear enough to see the immersed seeds. A local calabash was thereafter used to strain out the stones and sand in the thoroughly washed seeds as is traditionally done with local rice.

Thereafter, $250 \mathrm{~g}$ of the seeds were weighed and boiled until soft (on the average $250 \mathrm{~g}$ of Breadfruit seed required $1200 \mathrm{mls}$ of water and approximately 130 minutes to cook using firewood). The cooking water was allowed to dry up completely. Thereafter, one tablespoonful palm oil, one tablespoonful ground dry fish (palamu), two medium sized onions and salt were added to taste. The specimen was then spread out on a tray in an open space until cold and thereafter packed in a polythene bag and labeled as sample B.

The third portion (C) was repeatedly washed in tap water until the seeds were clearly seen through the water. A local calabash was thereafter used to strain out the stones and sand in the thoroughly washed seeds as is usually done with the local rice.

Thereafter, $250 \mathrm{~g}$ of the seeds were weighed out and parboiled (on the average $250 \mathrm{~g}$ of Breadfruit seed required $600 \mathrm{mls}$ of water and approximately 60 minutes to partially cook using firewood). One tablespoonful palm oil, one tablespoonful ground dry fish (palamu), two medium sized onions and salt were added to taste. The cooking water was allowed to evaporate. The specimen was then spread out on a tray and allowed to cool.

Two hundred grams of this were taken and further toasted in a frying pan until they appeared golden brown and dropped freely from the cooking spoon. This was cooled in the open air and transferred into a polythene bag and labeled sample $\mathrm{C}$.

\section{Determination of proximate composition of raw seed-A, cooked seed -B and toasted seed-C}

The proximate composition of the Breadfruit seed flours was determined in triplicate using the methods of the AOAC [15]. Moisture content was determined using the electric oven method at $105^{\circ} \mathrm{C}$ for 12 hours. Crude protein was determined using Foss 


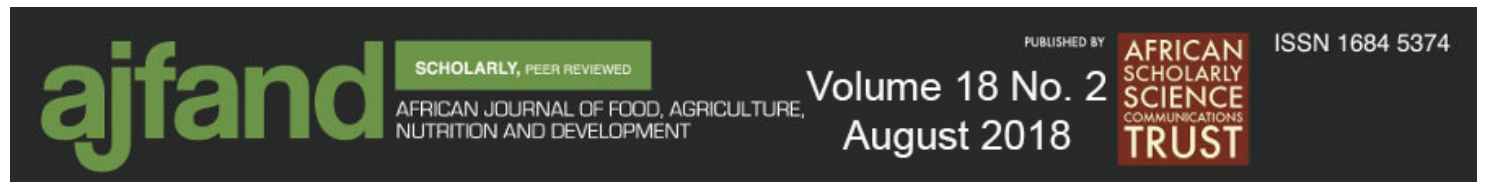

Kjeltech ${ }^{\mathrm{TM}}$ auto distillation unit (8200, Type: 10014901-Hilleroed, Denmark) and calculated as \%Nitrogen X6.25. Crude fat was determined using the Soxhlet extraction method and the total ash was determined by dry ashing in an electric furnace at $550^{\circ} \mathrm{C}$ for 8 hours. Crude fiber content was estimated by consecutive acid and alkali digestion of the samples followed by washing, drying and ashing at $600{ }^{\circ} \mathrm{C}$. The total carbohydrate was determined by difference.

\section{Determination of caloric values of samples}

Caloric values of dry flour of the samples were calculated based on the energy value available per kg of the macronutrient. Total energy was calculated using Atwater Factors: Energy value $=\%$ Protein $\mathrm{x} 4+\%$ Carbohydrate $\mathrm{x} 4+\%$ Fat $\mathrm{x} 9$ [16].

\section{Quantification of anti-nutrients}

Tannin content was determined by the modified Vanillin $-\mathrm{HCl}$ method using $1.0 \mathrm{mg} / \mathrm{ml}$ of Catechin in $1 \% \mathrm{HCl}-\mathrm{MeOH}$ as standard. The intensity of the coloured substituted product so produced was measured using a spectrophotometer at 500nm [17]. Phytate content was determined by titration method as described by Wheeler and Ferrei using $\mathrm{FeCl}_{3}$ as standard [18].

\section{Statistical analysis}

Results were expressed as mean and standard deviation using Statistical Package for Social Sciences (SPSS) version 20 as the software package for analysis. Analysis of Variance (ANOVA) was used to compare the significance of the sample means. Multiple Comparisons was carried out to determine the significant difference in the pairs of the means using Least Significant (LSD) method. A p- value $<0.05$ was considered to be significant.

\section{RESULTS}

Table 1 shows the proximate composition of Raw seed-A, Cooked seeds-B and Toasted seeds-C. For the moisture content, the \% mean of the raw seeds had the highest value (8.40), followed by cooked seeds (8.38). There was a statistical significant difference in the means ( $p$-value $=0.001$ ). The multiple comparison showed that statistical significant differences in moisture content occurred between raw and toasted seeds ( $p$-value $<0.05)$, toasted and cooked seeds ( $\mathrm{p}$-value $<0.05$ ) but not between raw and cooked seeds.

For the ash, the cooked and toasted seeds had \% means of 1.86 and 1.83 , respectively while raw seeds had the least $(1.36 \%)$ mean value. There were statistically significant differences in the average ash contents of the samples ( F-value $=105.91, p<0.05)$. Differences occurred between raw and toasted seeds as well as raw and cooked seeds ( $\mathrm{p}$ value $=0.05)$.

Considering the $\%$ means of the fat and crude fiber, toasted seeds had the highest $\%$ mean values for both parameters (13.74 for fat and 2.39 for crude fiber). There were statistical significant differences between the means of the two proximate $(\mathrm{p}<0.05)$. For fat, statistical significant differences occurred between the raw and toasted seeds as well as in the toasted and cooked seeds. For crude fiber, statistical significant differences 


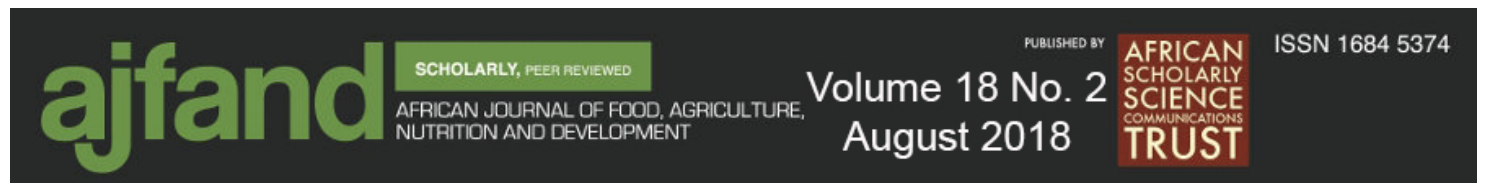

occurred in the following: raw and toasted, raw and cooked, and toasted and cooked ( $\mathrm{P}<$ $0.05)$.

Further, the \% protein in cooked seeds $(18.25 \%)$ was the highest followed by toasted seeds $(17.22 \%)$. There was statistical significant difference in the means $(F=580.46$, $\mathrm{p}<0.05)$. Statistical significant differences occurred in the following combinations: raw and toasted, raw and cooked, and toasted and cooked $(\mathrm{P}<0.05)$.

The mean carbohydrate contents of the raw, cooked and toasted seeds were 65.9, 66.3 and $64.8 \%$, respectively. The mean energy values ranged between 427.84 for raw seeds, 441.52 for cooked seeds and $451.82 \mathrm{Kcal} / 100 \mathrm{~g}$ for toasted seeds. Carbohydrate and energy did not show any statistical differences in their mean values $(p>0.05)$. None of the two methods of traditional processing resulted in significant increases in the carbohydrate and energy content of the product ( $\mathrm{F}=0.092$ and 1.58 , respectively).

The anti-nutritional components (phytate and tannin) of Raw, Cooked and Toasted seeds of African Breadfruit are shown in Table 2. Cooked seeds had the highest value $(3.50 \mathrm{mg} / \mathrm{g})$ followed by toasted seeds $(2.32 \mathrm{mg} / \mathrm{g})$ for tannin. There was statistical significant difference $(\mathrm{p}<0.05)$. Statistical significant differences also occurred in the following combinations: raw and toasted, raw and cooked, and toasted and cooked $(\mathrm{P}<$ $0.05)$. Phytate had means of $2.85,2.01$ and $2.24 \mathrm{mg} / \mathrm{g}$ for raw, cooked and toasted seeds, respectively $(F=56.51, p<0.05)$. Statistical significant differences occurred between raw and toasted, raw and cooked but not between toasted and cooked $(\mathrm{P}<0.05)$.

As shown in Table 3, the proximate compositions of raw seeds purchased within the same region (South West Nigeria) were comparable.

\section{DISCUSSION}

The strength of this study is in the fact that the processing methods replicated the usual traditional cooking methods within the community. Biomass energy (used in preparing the samples for this study) is the most prevalent means of cooking within the Ikenne local government [19]. Hence, the final products used in this study were exactly the same as those normally eaten by the rural populace having added the usual traditional cooking condiments.

Studies have shown that the nutrient composition and anti-nutrients found in the seeds of Treculia africana are affected by various factors; for example, geographical location of the tree [20], duration of storage [11], and process of de-hulling [8]. In one study, fresh raw seeds had carbohydrate, crude protein, moisture, crude fiber, ash and ether extract (fat) contents of $38.26,17.67,3.82,15.85,3.97$ and $15.85 \%$, respectively which became $36.0,18.5,3.1,15.4,2.7$ and $10.1 \%$, respectively after just 1 week of room storage/drying. These figures got lower as the duration of storage increased except for crude fiber and ash which followed an opposite trend [11].

As shown in Table 3, the proximate composition of the raw seeds that were used for this study was similar to that reported by Nwokocha using seeds procured from Ibadan also 


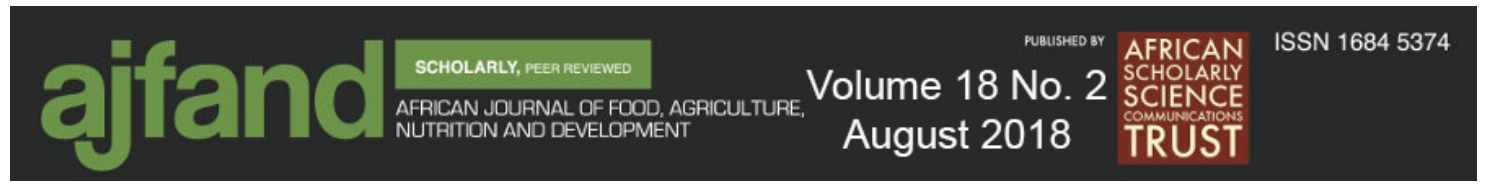

in the South West Nigeria [20] and unlike other seeds from the South East (SE) and South South (SS) Nigeria [11].

In this study, the moisture content in the raw seed (8.4\%) was comparable to what was reported by Osabor $(8 \%)$ and Aruey $(9 \%)[21,22]$. It was much higher than the $3.3 \%$ and $3.8 \%$ reported by Nwaigwe [23] and Onyekwelua [11], respectively and lower than the $10.8 \%$ values reported by Appiah [24].

The differences may be attributed related to the location where the seeds were purchased. The fact that the composition of the seeds from the African Breadfruit tree varies from tree to tree has been highlighted in other studies [11, 25]. In a majority of the rural community where the African Breadfruit seed is processed, sun drying has been reported to be the major means of preservation [8], especially as its fruiting is seasonal- March to July [26]. Hence, drying varies from one harvester to the other and the moisture content depends on the time of the year that the seeds were procured in the market.

Since toasting significantly reduced the $\%$ moisture content, it is plausible that this could enhance a prolonged shelf life of the toasted seed if properly protected from other external conditions. The toasted seeds can, therefore, be useful as a complementary food for busy working mothers in the cities.

The crude fiber in toasted and cooked porridge in this study fell within the range reported for some Nigerian vegetables [27]. Crude fiber is the insoluble polymeric material of plant cell walls such as cellulose, hemicelluloses, pectin and lignin that constitute the major part of dietary fiber [28]. A high fiber intake has been linked with decreased chances of colon cancer and associated with reducing constipation. In addition, intake of dietary fiber has the potential to protect against cardiovascular diseases, diabetes, obesity, colon cancer and other diverticular diseases [29]. Codex Alimentarius Commission indicated that the crude fiber content for weaning foods should not be greater than $5 \%$ [30]. Neither of the traditional processing methods used in this study increased the $\%$ crude fiber to this level. Consequently, the low crude fiber content of the toasted and cooked seeds suggested they could be suitable in weaning diets as their crude fiber was less than the recommended $5 \%$.

The two traditional preparation methods resulted in significant increase in protein content. Although toasting yielded a much lower increase, its protein content was still similar to that reported for Bambara Groundnut [31]. Sometimes, flours may be blended with other food of higher protein to provide needed nutrients [32]. Proteins are increasingly being utilized to perform functional roles in food formulations. Therefore, the protein content of the three groups in this study suggests that they may be useful in food systems where protein functionality is needed, and also contribute to the recommended daily intake of proteins for adults (34-56g/day) and children (13-19g/day) [33]. Irrespective of the mode of processing, the African Breadfruit's protein content was way above the $12 \%$ protein recommended for a food to be considered as a protein source [33]. 


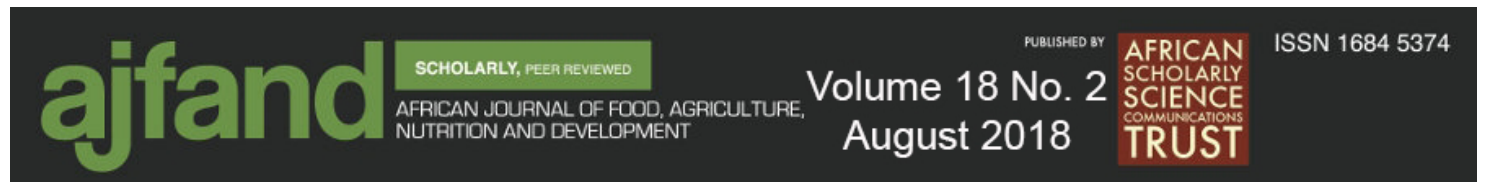

Fats are essential in diets as they increase the palatability of foods by absorbing and retaining their flavors, in addition to being vital in the structural and biological functioning of cells and in the transport of nutritionally essential fat -soluble vitamins [34]. Water and fat are the major determinants of dietary energy density with water having the greatest effect. Protein and carbohydrates contribute minimally to dietary energy density. In general, the energy density of ready- to- eat food is largely determined by a fat-water seesaw with energy density falling when there is higher water content and fall in fat content [35]. Energy density rises when water content drops and fat content rises. This was what happened when the seeds were toasted as the moisture content dropped and the fat content and thus energy increased. The high fat content in the toasted seed studied would, therefore, make it a better source of energy than the cooked seed and could be a better flavor enhancer.

Carbohydrates are good sources of energy and their high concentration is desirable in breakfast meals and weaning formulae. In this regard, therefore, the high carbohydrate content of the seeds would make them good sources of energy in breakfast formulations.

Treculia africana seed is a rich source of vegetable oil (10\%), protein $(17 \%)$, and carbohydrates (40\%), as well as a number of minerals and vitamins [36].

The ash content of a food item is a close reflection of the mineral content. As the ash in the raw seed significantly increased in the cooked and toasted preparations, it can be inferred that the mineral content would have increased in the two samples.

Tannins are water soluble phenolic compounds with a molecular weight greater than 500 . There have been conflicting reports about tannins in human nutrition [37]. Whilst some reported its ability to precipitate proteins from aqueous solution [25], thereby making the proteins biologically unavailable, other studies have reported favorably on tannins. Fiori et al. [38] found a positive correlation between tannin concentration and antifungal activity. Olivierira [12] reported on the antibiotic and antifungal properties of tannins. Similarly, Runsewe-Abiodun reported alleviation of skin rash in children fed on the African Breadfruit diet from the same locality [10]. The tannin content reported in this study appeared to have increased with the traditional preparation methods and it was highest with the cooked diet. Although traditional preparations resulted in significantly higher tannin levels in the toasted seed and porridge, the level of tannin in each of the three groups was much lower when compared to tannin reported by Hassan et al. [39] for Melocia corchorfolia leaves and Cleome rutidosperma $(46.89 \pm 0.02 \mathrm{mg} / \mathrm{g}$ and 152.5 $\pm 0.1 \mathrm{mg} / \mathrm{g}$, respectively) for unconventional vegetable commonly consumed in Adamawa State, Nigeria. Therefore, the levels of tannin in the seeds will not pose any toxicity threat.

Phytate is known to decrease the bioavailability of minerals, especially $\mathrm{Ca}, \mathrm{Mg}, \mathrm{Fe}$, and $\mathrm{Zn}$ [38]. Hurrel et al. [40] reported that a phytic acid intake of 4-9mg/100g dry matter decreases iron absorption 45-fold in humans. On the other hand, it is considered to be an anti-carcinogen that protects against colon cancer and a potent antioxidant that inhibits Fenton reactions leading to lipid peroxidation and inhibition of polyphenol oxidase. In spite of this apparent usefulness of phytates, cooking has been reported to eliminate anti- 


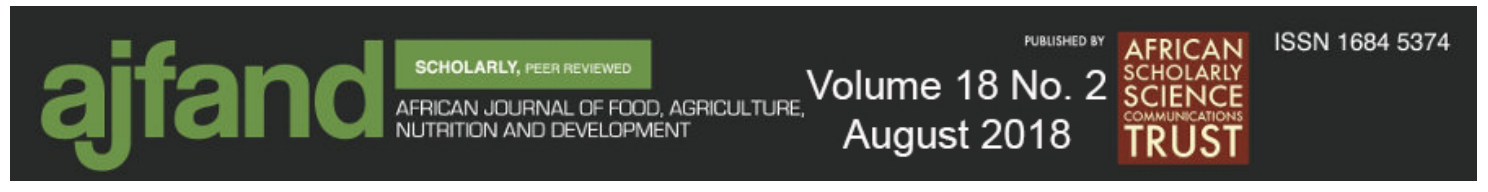

nutritional factors [41]. This was borne out of this study where the phytate levels in the cooked and toasted seeds were much lower than in the raw seeds.

\section{CONCLUSION}

The study results showed that the two major modes of preparation of the African Breadfruit seeds in the community yielded meals that are of high nutritive value coupled with low anti-nutrient levels. The meal/snacks can be useful as good complementary diets for the African child especially in areas where it grows wildly as it will provide a more viable alternative to the currently known and consumed weaning diets among the rural populace. Toasting the African Breadfruit seed would be particularly beneficial for working mothers in cosmopolitan areas that require ready- to- eat food as the shelf life will possibly be increased by this method of processing.

It is, therefore, recommended that the African Breadfruit seeds as prepared and eaten within the communities especially where it grows wildly be included as good complementary diets for infants and young children.

Large-scale production of this well- known food items will be encouraged if Technical schools develop machines that will make its production less laborious as studies have shown that majority of the harvesters do so for domestic/household consumption purposes only.

\section{Acknowledgements}

The authors hereby acknowledge the assistance of Dr Adekunle D Alabi for the data analysis. The assistance of Miss Kafayat K Ogunnowo in the preparation of the study samples is appreciated.

\section{Competing Interest}

The authors declare no competing interest.

\section{Authors' contributions}

Runsewe-Abiodun conceived and designed the study and contributed to the initial draft, Oritogun contributed to data analysis and wrote the results, Aliyu interpreted the data and contributed to the initial draft.

All authors read and approved the final draft. 


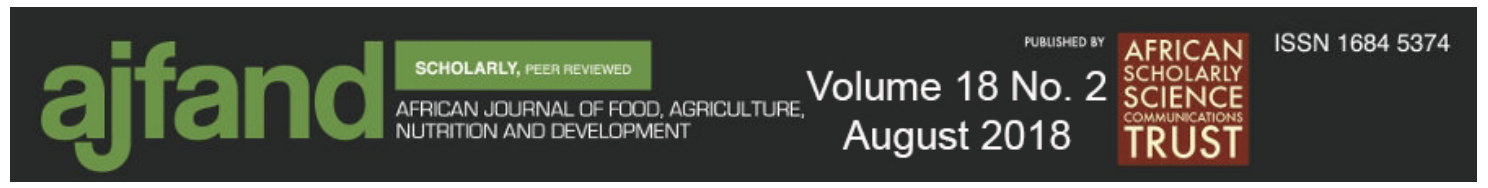

Table 1: The Proximate composition* of Raw, Cooked diet and Toasted seed of African Breadfruit

\begin{tabular}{llllll}
\hline $\begin{array}{l}\text { Proximate } \\
\text { Composition } \\
(\%)\end{array}$ & Raw seed & Cooked diet & Toasted seed & F-value & P-value \\
& & & & & \\
\hline Moisture & $8.40 \pm 0.101$ & $8.38 \pm 0.006$ & $7.37 \pm 0.045$ & 169.21 & 0.001 \\
Ash & $1.36 \pm 0.053$ & $1.86 \pm 0.039$ & $1.83 \pm 0.011$ & 105.91 & 0.002 \\
Fat & $10.98 \pm 0.071$ & $11.50 \pm 0.135$ & $13.74 \pm 0.234$ & 165.30 & 0.001 \\
Crude Fiber & $1.25 \pm 0.007$ & $2.13 \pm 0.014$ & $2.39 \pm 0.064$ & 499.50 & 0.000 \\
Protein & $16.31 \pm 0.088$ & $18.25 \pm 0.007$ & $17.22 \pm 0.042$ & 580.46 & 0.000 \\
Carbohydrate & $65.93 \pm 6.093$ & $66.27 \pm 0.074$ & $64.83 \pm 0.329$ & 0.092 & 0.915 \\
Energy(Kcal) & $427.84 \pm 23.383$ & $441.52 \pm 0.885$ & $451.82 \pm 0.959$ & 1.58 & 0.339 \\
\hline *All values are means of triplicate \pm standard deviation (SD) & &
\end{tabular}

Table 2: Anti-nutritional component* of Raw, Cooked Diet and Toasted seed of African Breadfruit

\begin{tabular}{llllll}
\hline Anti- & Raw seed & Cooked & Toasted & F-value & P-value \\
nutritional & & & & \\
Component & & & & \\
\hline Tannin & $2.18 \pm 0.020$ & $3.50 \pm 0.010$ & $2.32 \pm 0.003$ & 6332.83 & 0.000 \\
(mg/g) & & & & & \\
Phytate & $2.85 \pm 0.095$ & $2.01 \pm 0.046$ & $2.24 \pm 0.095$ & 56.51 & 0.004 \\
(mg/g) & & & & & \\
\hline *All values are means of triplicate \pm standard deviation (SD)
\end{tabular}




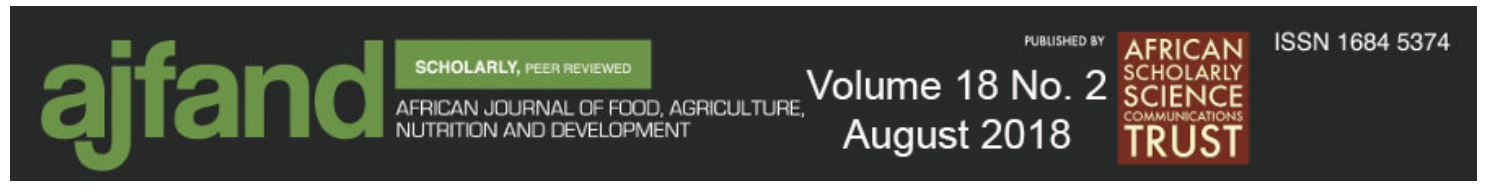

Table 3: Proximate composition of raw Treculia africana seeds from different parts of the sub-region

\begin{tabular}{lllllllll}
\hline Proximate & \multicolumn{6}{c}{ Sources of Raw Treculia africana Decne seeds in the sub-region* } \\
composition (\%) & $\mathbf{1}$ & $\mathbf{2}$ & $\mathbf{3}$ & $\mathbf{4}$ & $\mathbf{5}$ & $\mathbf{6}$ & 7 \\
\hline FAT & 10.98 & 10.6 & 15.8 & 4.21 & 12.84 & 15.67 & 9.08 \\
PROTEIN & 16.6 & 16.3 & 17.67 & 12.5 & 18.39 & 25.62 & 17.57 \\
MOISTURE & 9.5 & 8.4 & 3.82 & 8.0 & 9.28 & 3.33 & 10.81 \\
CRUDE FIBER & 1.2 & 0.85 & 1.58 & 1.6 & 3.16 & 4.64 & 2.91 \\
ASH & 1.4 & 0.99 & 3.97 & 2.26 & 4.70 & 4.33 & 2.64 \\
CARBOHYDRATE & 59.75 & 65.9 & 38.2 & 73.2 & 51.63 & 43.49 & 57.00 \\
\hline
\end{tabular}

*Site of purchase of raw Treculia africana seeds with references

1. Ogere, Ogun State, South West Nigeria (This study)

2. Ibadan, Oyo State, South West, Nigeria[17]

3. Akure, Ondo State Oyo State, South West, Nigeria[18]

4. Calabar, Cross-River State, South-South, Nigeria [20]

5. Anambra State, South East Nigeria [21]

6. Isiala-Mbano Local Government, Imo State, South East, Nigeria [22]

7. Ghana [23] 


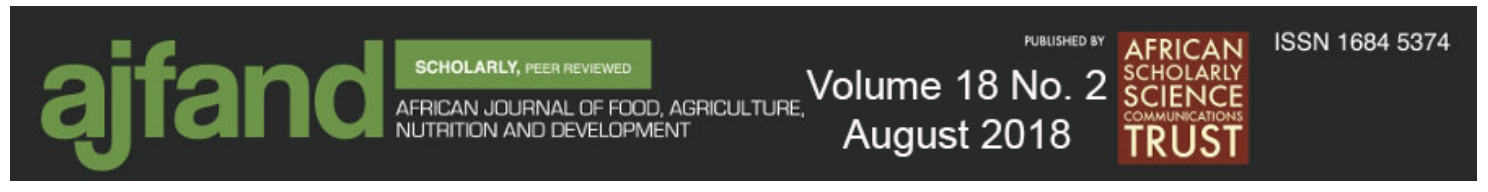

\section{REFERENCES}

1. Iqbal A, Khalil IA, Ateeq $\mathbf{N}$ and MS Khan Nutritional Quality of Important Food Legumes. Food Chemistry 2006; 97(2):331-335.

2. Powell K Functional foods from biotech an unappetizing prospect? Nat. Biotechnol.2007; 25: 525 - 531.

3. Allen LHB Vitamins: Proposed fortification levels for complementary foods for young children. J. Nutr. 2003; 133: 3000-3007.

4. Dewey KG and S Adu-Afarwuah Systematic review of the efficacy and effectiveness of complementary feeding interventions in developing countries. Matern Young Child Nutr. 2008; 4: 24- 85.

5. Onofiok NO and DO Nnanyelugo Weaning foods in West Africa: National problems and possible solutions. http://unu.edu (accessed 31 July 2016).

6. Nnorom IC, Ewuzie U, Ogbuagu F, Okereke M, Agwul I and IP Enyinnaya Mineral Contents of Ukwa, African Breadfruit (Treculia africana), from SouthEastern Nigeria: Effect of Methods of Preparation. International Journal of Plant \& Soil Science 2015; 4(3): 230-240.

7. Adumanya OC, Akunna TO, Onwusonye JC and GA Obi-Adumanya The effects of traditional processing methods on mineral contents of African Breadfruit (Treculia africana) seeds. International Science Research Journal 2013; 4(2):2326.

8. Ugwu CS and JC Iwuchukwu Processing and preservation of African bread fruit (Treculia africana) by women in Enugu North agricultural zone, Enugu State, Nigeria. African Journal of Agricultural Research 2013; 8(11): 984-994.

9. Olapade AA and UC Umeonuorah Mineral, Vitamin and Antinutritional Content of African Breadfruit (Treculia africana) Seeds Processed with Alum and Trona. Journal of Environmental Science, Toxicology and Food Technology 2013; 5 (5): 71-78.

10. Runsewe-Abiodun I, Olowu OA and DM Olanrewaju Efficacy of the African Breadfruit (Treculia Africana) in the Nutritional Rehabilitation of Children with Protein- Energy Malnutrition. Nigerian Journal of Paediatrics 2001; 28: 128-134.

11. Onyekwelua JC and JO Fayose Effect of Storage Methods on the Germination and Proximate Composition of Treculia Africana Seeds. Tropentag2007. University of Kasel-Witzenhausen and University of Gottingen. Conference on International Agricultural Development. 
12. Olivierira AM, Mesquita MS, Silva GC, Lima EO, Medeiros PI, Paiva PMG, Souza IA and TH Napoleao Evaluation of toxicity and Antimicrobial activity of an Ethanolic extract from leaves of Morus alba L (Moraceae). Evidence-Based Complementary and Alternative Medicine 2015; Volume 2015 (2015), Article ID 513978, 7 pages. http://dx.doi.org/10.1155/2015/513978 (accessed 24 April 2018)

13. Badifu GO and EM Okeke Effect of blanching on oxalate, hydrocyanic acid and saponin content of four Nigerian leafy vegetables. J. Agric. Sci. \& Tech.1992; 2 (1):71-75.

14. Balogun AM and BL Fetuga Chemical composition of some under exploited leguminous crop seeds in Nigeria. J. of Agric. Fd. Chem. 1986; 34: 189-192.

15. AOAC. Official Methods of Analysis International. $17^{\text {th }}$ Edition, Association of Official Analytical Chemists, Washington DC.2000.

16. Chinnasammi G, Bernard WC, Sathiyasekaran P, Perumal T and R Chellan Nutritional Evaluation, in vitro Free Radical Scavenging and in vivo Antiinflammatory Effects of Gisekia pharnaceoides and Identification of Kaempferol as a Nutraceutical Agent. British Biotechnology Journal 2011; 1(3):113-135.

17. Price ML, Scoyoc SV and LG Butler A critical evaluation of the vanillin reaction as an assay for tannin in sorghum grain. Journal of Agricultural and Food Chemistry 1978; 26: 1214-1218.

18. Wheeler EL and RE Ferrel A method for phytic acid determination in wheat and wheat fractions. Cereal Chemistry 1971; 48: 312-320.

19. Nwokocha LM and JO Ugbomoiko Effect of Parboiling on the Composition and Physicochemical Properties of Treculia africana Seed Flours. Pakistan Journal of Nutrition 2008; 7(2): 317-320.

20. Osabor VN, Ogar DA, Okafor PC and GE Egbung Profile of the African Bread Fruit (Treculia africana).Pakistan Journal of Nutrition 2009; 8(7): 1005-1008.

21. Arueya GL and JK Iloghalu Development and evaluation of African Breadfruit (Treculia africana) based ready-to-cook food product for the elderly. African Journal of Food Science and Technology 2013; 4(10): 229-239.

22. Nwaigwe JO and BA Adejumo Qualities of African Breadfruit (Treculia Africana) Seed Flour as Influenced by Thermal Processing Methods and Duration. International Journal of Technology Enhancements and Emerging Engineering Research 2015; 3 (4):102.

23. Appiah F, Oduro I and WO Ellis Pasting properties of Treculia africana seed flour in Ghana and the production of a breakfast meal. Agric. Biol. J. N. Am, 2011; 2(2): 325-329. 


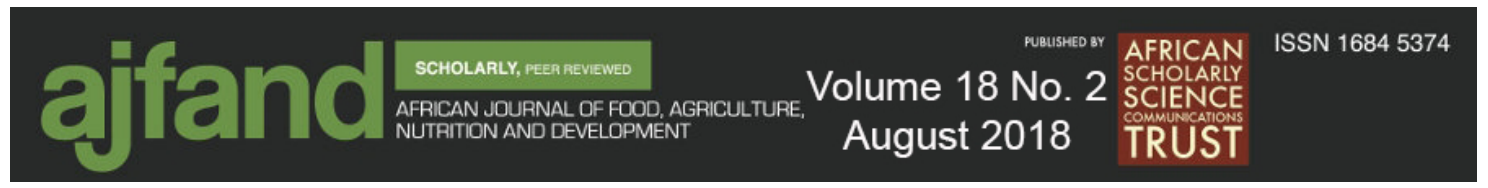

24. Nwokocha LM and PA Williams Structure and properties of Treculia africana, (Decne) seed starch. Carbohydrate Polymers 2011; 84: 395-401.

25. Okafor GI and FC Ugwu Production and evaluation of cold extruded and baked ready to eat snacks from blends of Breadfruit (Treculia africana), cashewnut (Anarcardium occidentale) and coconut (cocos nucifera). Food Science and Quality Management2014; 23:65-77.

26. Agbaire PO and OO Emoyan Nutritional and anti- nutritional levels of some local vegetables from Delta State, Nigeria. African Journal of Food Science 2012; 6(1): $8-11$.

27. Johnston DE and WT Oliver The influence of cooking technique on dietary fiber of boiled potato. Journal of Food Technology 1982; 17: 99-107.

28. McPherson J Dietary fiber - A perspective. In: CRC Handbook of dietary fiber in Human Nutrition. Spiller GA (ed.). CRC Press, Boca Raton, 1992: 7-14.

29. Codex Alimentarius Commission Amendment Regulations. The Processed CerealBased Foods for Infants and Young Children (2000).

30. Eltayeb ARS, Ali M, Arab AAA and FMA Salem Chemical composition and functional properties of flour and protein isolate extracted from Bambara groundnut (Vigna subterranean). Afr. J. Food Sci.2011; 5(2): 82-90.

31. Zhao W, Zhai F, Zhang D, An Y, Liu Y, He Y, Ge K and NS Scrimshaw Lysine fortified wheat flour improves the nutritional and immunological status of wheat eating families in Northern China. Food and Nutrition Bulletin 2004; 25: 114-122.

32. Food and Nutrition Board (FNB). Dietary reference intake for energy, carbohydrate, fiber, fatty acids, cholesterol, protein and amino acids. Food and Nutrition Board, Institute of Medicine. National Academy Press. (KH) Washington, DC, 2002: 422-541.

33. Aiyesanmi AF and MO Oguntokun Nutrient composition of Dioclea reflexa seed-an underutilized edible legume. Rivista Italiana Delle Sostanze Grasse 1996; 73: 521-523.

34. Allen $\mathbf{L}$ and A Prentice The combined effects of macronutrients and energy density on energy intake. Encyclopedia of human nutrition, four-volume set. https://books.google.com.ng.books (accessed 08/02/108).

35. Etoamaihe $\mathbf{U J}$ and KC Ndubueze Development and performance evaluation of a dehulling machine for African Breadfruit (Treculia Africana) J. Eng. Appl. Sci. 2010;5(4): 312- 315.

36. Chung KT, Wong TY, Wei CI, Huang YW and Y Lin Tannins and human health: A review. Crit Rev Food Sci Nutr 1998; 38(6):421-64. 


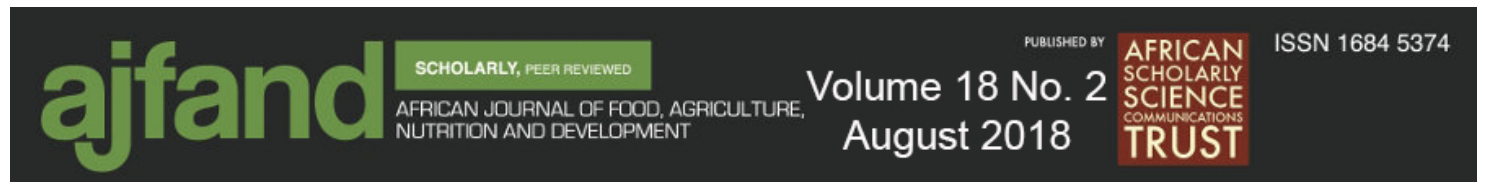

37. Fiori GML, Fachin AL, Correa VSC, Bertoni BW, Giulliatti S, Amui SF, Franca SC and AMS Pereira Antimicrobial Activity and Rates of tannins in Stryphnodendron adstringens Mart. Accessions collected in the Brazilian Cerrado. American Journal of Plant Sciences 2013; 4: 2193-2198.

38. Hassan LG, Umar KJ, Dangoggo SM and AS Maigandi Anti-nutrient composition and bioavailability prediction as exemplified by Calcium, Iron and Zinc in Melocia corchorifolia leaves. Journal of Nutrition 2011; 10(1): 23-28.

39. Hurrel RF, Juillert MA, MB Reddy, Lynch SR, Dassenko SA and JD Cook Soy protein, phytate and iron absorption in humans. American Journal of Clinical Nutrition 1992; 56: 573-578.

40. Alajaji SA and TA El-Adawy Nutritional composition of chickpea (Cicer arietinum L.) as affected by microwave cooking and other traditional cooking methods. J. Food Compos. Anal.2006; 19: 806-812. 